\title{
Late Pleistocene and Holocene climatic variability in the Carpathian-Balkan region
}

\author{
Marcel Mîndrescu', ${ }^{1,2}$ and lonela Grădinaru ${ }^{1,2}$ \\ CBW2014, Cluj-Napoca, Romania, 6-9 November 2014
}

Prior to the last decade, the Carpathian region was largely unrepresented in large data reviews (Akinyemi et al. 2013) on well-dated, high-resolution investigations of past climate and environmental conditions and in studies on human impact on the local and regional environment. However, more recently, as new paleoclimatic records are continuously being generated, the area has ceased to be regarded as a blank spot in regional and continental-scale climate reconstructions (e.g. Feurdean et al. 2014). Undoubtedly, improving knowledge of the region in terms of past and current climate change research, biodiversity patterns and dynamics, or human spread and related cultural-technological interchanges will be accomplished only through a denser network of multi-proxy investigations (Veres and Mîndrescu 2013).

In 2011, a workshop co-sponsored by PAGES and the Mountain Research Initiative (MRI), and focusing on climatic variability in the Carpathian-Balkan region (CarpathianBalkan Workshop, CBW2011, Suceava, Romania) was an early and successful attempt to create a network of paleoscientists in the region (Mîndrescu 2012). An initial product from this new network was a special volume in Quaternary International on the advances in Pleistocene and
Holocene climate changes research from the Carpathian-Balkan region (Veres and Mîndrescu 2013).

The latest workshop, CBW2014, was another step forward for paleo-research in the region. The outcomes of several collaborations emerging from CBW2011 were presented, and new international research topics were discussed. Furthermore, the event provided a platform for young scientists to introduce and discuss their results to an international and multidisciplinary audience.

Sixty-two researchers from 11 countries (Canada, UK, Switzerland, Germany, Poland, Hungary, Ukraine, Bulgaria, Bosnia and Herzegovina, Serbia, and Romania) conducting studies in the Carpathian-Balkan region presented over 60 contributions covering the timeframe from the Late Pleistocene to the present. Topics included climate and vegetation changes inferred from lacustrine and riverbed sediments, tree rings, speleothems, loess-paleosol sequences, and glaciers and glaciation; refining research techniques for paleoenvironmental investigations; human impacts; archeological findings; etc. The abstracts and extended abstracts were published prior to the event in an open-access special issue of Georeview

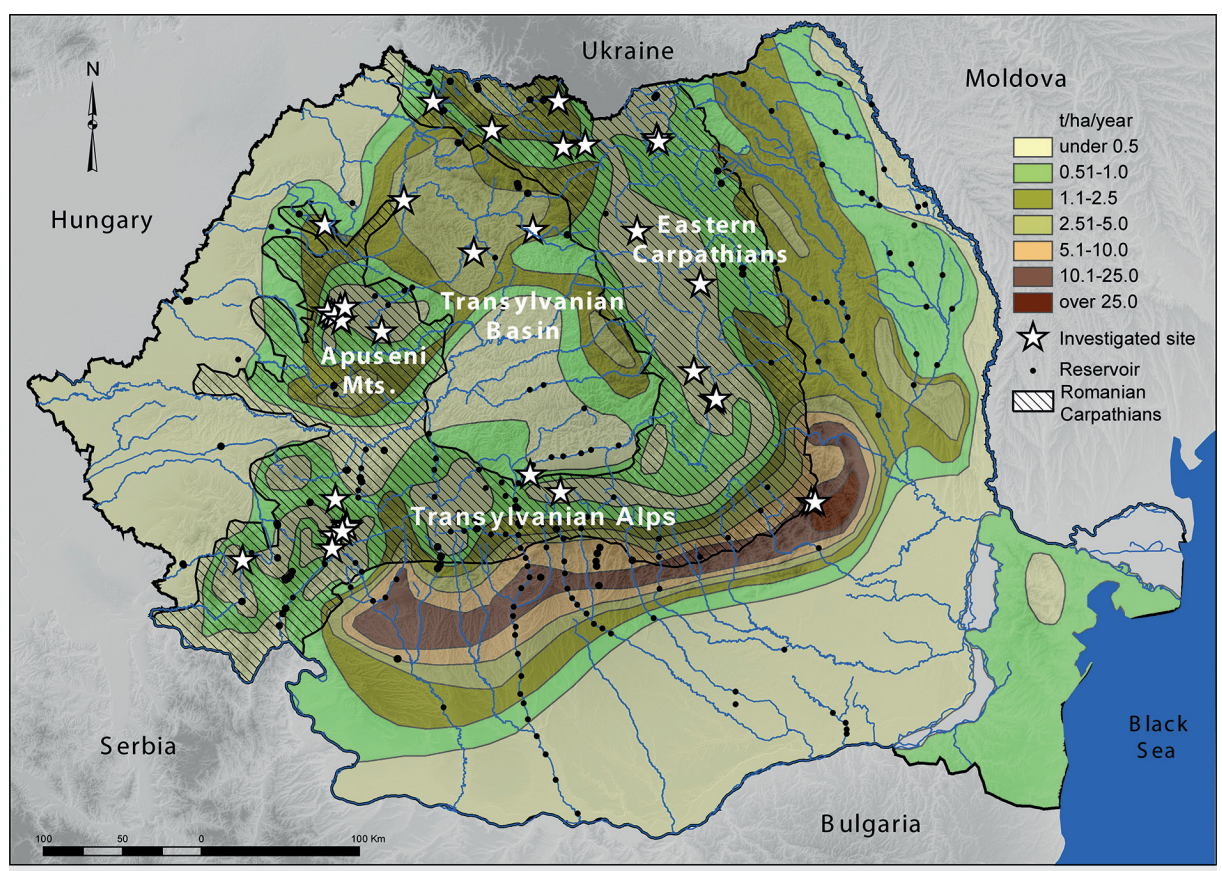

Figure 1: Location of sites with lacustrine sediment records in the Romanian Carpathians (modified from Mîndrescu et al., in press).

(http://georeview.ro/ojs/index.php/revista/ issue/view/CBW-2014).

The range of data from recent research in the region presented at the workshop (including two datasets on glacial lakes, http://atlas.usv.ro/geoconcept/webcarpath2/ and glacial cirques from the Romanian Carpathians, http://atlas.usv.ro/geoconcept/ glaciar/) is in itself an accomplishment as those records contribute in covering previously "uncharted" territory. Further, the meeting participants envisaged using the new datasets as a basis for new research endeavors which could integrate and relate data from this growing network of sites (see Fig. 1).

The more advanced contributions presented at the meeting will be published in a special volume in Quaternary International, to be guest edited by the organizers of the workshop: more than 30 author groups have already committed to submitting a paper.

Finally, in the plenar discussion, the participants agreed that without better data coverage and expertise exchange, difficulties will remain in understanding local-scale environmental changes and developing regionally significant paleoclimate reconstructions, which would assist in proposing plausible predictions of future climate evolution.

\section{AFFILIATIONS}

'Department of Geography, University of Suceava, Romania

${ }^{2}$ Geoconcept Association of Applied Geography, Suceava, Romania

\section{CONTACT}

Marcel Mîndrescu: marcel.mindrescu@gmail.com REFERENCES

Akinyemi FO et al. (2013) Quat Int 293: 105-113 Feurdean A et al. (2014) Quat Sci Rev 106: 206-224 Mîndrescu M (2012) PAGES news 20: 54

Mîndrescu M et al. (in press) In: (Eds) Radoane M and Vespremeanu-Stroe A (2015) Landform Dynamics and Evolution in Romania, Springer Veres D, Mîndrescu M (2013) Quat Int 293: 1-4 